\title{
The infrared camera: a tool for mountain lakes research
}

\author{
Adam Choiński ${ }^{1}$, Tomasz Heese ${ }^{2}$, Tomasz Oberski ${ }^{3}$ \\ ${ }^{1}$ Adam Mickiewicz University in Poznań, Institute of Physical Geography and Environmental Planning, Department of Hydrology and \\ Water Management, Dzięgielowa 27,61-680 Poznań, Poland, e-mail: choinski@amu.edu.pl (corresponding author) \\ ${ }^{2}$ Koszalin University of Technology, Department of Civil and Environmental Engineering and Geodesy, Division of Environmental \\ Biology, Sniadeckich 2, 75-453 Koszalin, Poland, e-mail: tomasz.heese@tu.koszalin.pl \\ ${ }^{3}$ Koszalin University of Technology, Department of Civil and Environmental Engineering and Geodesy, Division of Geoinformatics, \\ Śniadeckich 2, 75-453 Koszalin, Poland, e-mail: tomasz.oberski@tu.koszalin.pl
}

\begin{abstract}
During field research work an attempt was made to use an infrared camera in alpine conditions without the use of a plane. The images received as thermal pictures are of high value because they show a continuous record of temperature on the whole water surface. The scale of temperature diversity is very high and amounts to approximately $6^{\circ} \mathrm{C}$. It is necessary to take photos of this type at short time intervals. It will enable the circulation of waters which results in a change in water temperature to be captured. This research will also allow seasonal changes of water temperature to be seized, for example during summer stagnation, water freezing, destruction of the ice layer and also the influence of the coastal zone on shaping thermal conditions in the zone of coastal waters.
\end{abstract}

Key words: lakes, Tatra Mountains, infrared camera, lake surface temperature

\section{Introduction}

Standard temperature research of surface lake waters in Poland consists in a daily, single reading of the temperature in a coastal zone (Lange 1993; Choiński 1995). It is done by a mercury thermometer. There can be some objections regarding the location of measuring points and whether they reflect the temperature of the whole lake. The location of measuring points by the lake shore results from the fact that they are easily accessible during the whole year despite, for example, bad weather conditions.

The use of an infrared camera should demonstrate the wide range of its measurement possibilities. Thus, it will allow answers to be found to plenty of questions concerning whether the scale of temperature measurement at one measuring point is sufficient or whether the results obtained approximately reflect the average temperature. Additionally, the repeatability of shots allows certain phenomena to be captured, e.g. water circulation, the mechanism of ice formation, its destruction, the thermal conditions of water and land contact. It can be supposed that further research will be conducted precisely in this direction.
The review of Polish literature in the field of limnology indicates that the greatest attention has been given to water temperature (Choiński 2007). However, the infrared camera has hardly ever been applied. One of the few studies is the thermal plan of Lake Żarnowieckie, which indicated considerable variation in surface water temperature (Onoszko 1979).

\section{Study area and methods}

The aim of the study is to indicate that the infrared camera can be a very useful tool to research surface temperature of waters. However, the use of the camera is limited. One of the limits is taking photographs from certain heights (mostly from a plane), which is very expensive. Another barrier is weather conditions that can make taking photos impossible, for example intensive insolation, rain, fog, very low cloud ceiling, etc. Additionally, there is the need to have a plane at your disposal since photographs are taken repeatedly. These arguments prove that this type of camera is hardly ever used for water thermals research. In Poland this type of measurements was conducted on Żarnowieckie Lake and Pątnowskie Lake (unpublished study). 
The infrared camera Flir SC 660 was used during this research (Fig. 1). The camera has a detector which is a matrix of high definition with $640 \times 480$ pixels. It enables thermograms to be registered with no touch and with the use of measurement tools (point, line, rectangle, isotherm), different palettes of colours and the function such as fusion, which makes it possible to register images simultaneously within both visible light and infrared light. The high thermal sensitivity of the camera is estimated to be $30 \mathrm{mK}$, which provides very accurate measurements.

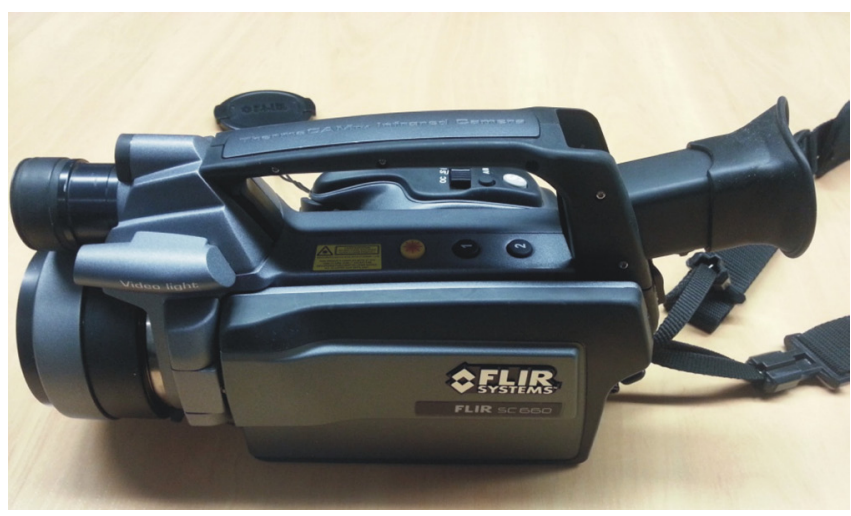

Fig. 1. Infrared camera

The camera has a standard germanium lens with a $24 \times 18^{\circ}$ field of vision and the construction of the lens prevents the exposure of the detector to visible light, letting through only electromagnetic waves from the infrared range. An extra device of the camera is a built-in GPS receiver which assigns visions to the geographic coordinates of the locations in which they were taken. The camera has a built-in LCD screen allowing the preview of registered images. Saved thermograms in the shape of 14-bit radiometric images (IPEG) are stored on SD cards with high capacity and which can be copied and analysed by special software (Flir, Quich Report, Matlab). The battery of the camera allows for continuous measurement of separate thermograms or their sequences for about 3 hours.

In this case two mountain lakes were selected for research. The lakes are Morskie Oko and Czarny Staw pod Rysami (Black Lake below Mount Rysy in English). The selection of mountain lakes eliminates the necessity of plane use. Moreover, it is possible to capture both lakes with the camera through relatively easy on foot access to the lakes. The repeatability of subsequent shots from precisely the same locations is also possible. Infrared camera photographs were tak- en on $11^{\text {th }}$ September 2012 between 4 p.m. and 9.30 p.m. The location of the shots presented below are as follows:

1 - last section of the route from Morskie Oko to Czarny Staw pod Rysami - approximately $180 \mathrm{~m}$ above Morskie Oko (Fig. 2)

2 - route from Czarny Staw pod Rysami to Rysy, from approximately $1750 \mathrm{~m}$ above Czarny Staw pod Rysami (see Fig. 7)

3 - viewing point in front of St. Staszica mountain hostel approximately $1410 \mathrm{~m}$ above sea level so the height difference between the surface of Morskie Oko was only about 15 m (see Fig. 12).

\section{Results}

The first thermal photos (Fig. 3) comprise the north part of Morskie Oko. The isotherms are presented by the adopted range of colours. Such photos give a "continuous" record in contrast to a spot record performed with the use of a thermometer. The unusual large variation in water surface temperature, which is almost $6^{\circ} \mathrm{C}$, is very surprising. The drop in temperature from the west shore to the east is clearly observed. The above configuration of isotherms is undoubtedly the effect of wind influence which moves surface waters giving such a "thermal image". Having obtained this configuration of isotherms, it can be seen that water temperature measurement conducted at a certain location and at a certain time and which refers to the whole surface of the lake can be very deceptive.

In the resulting thermal photograph (Fig. 3) two profile lines Li1 and Li2 were marked. In Figure 4 a precise run of temperature changes at a distance of 1 metre (horizontal axis) was observed. At the interface of water and land (with blocks of rock) the water is slightly warmer (in both cases) than at some distance from the shore. The reason for such conditions can be, for instance, heating water masses which are in contact with blocks of rock heated by insolation during the day, protecting the coastal zone from intensive wind impact, better heating of waters at low depths due to their small heat capacity, etc. In the case of profile Li1 a distinct breakdown of the curve is about 85 $\mathrm{m}$ from the shore and in the case of profile Li2 much closer to the shore: about $20 \mathrm{~m}$. In the case of both profiles the differences between maximum and minimum temperature in a given profile are relatively close and are respectively $4.4^{\circ} \mathrm{C}$ and $5.6^{\circ} \mathrm{C}$. It must be stated, however, that profile Li2 is three times shorter. 


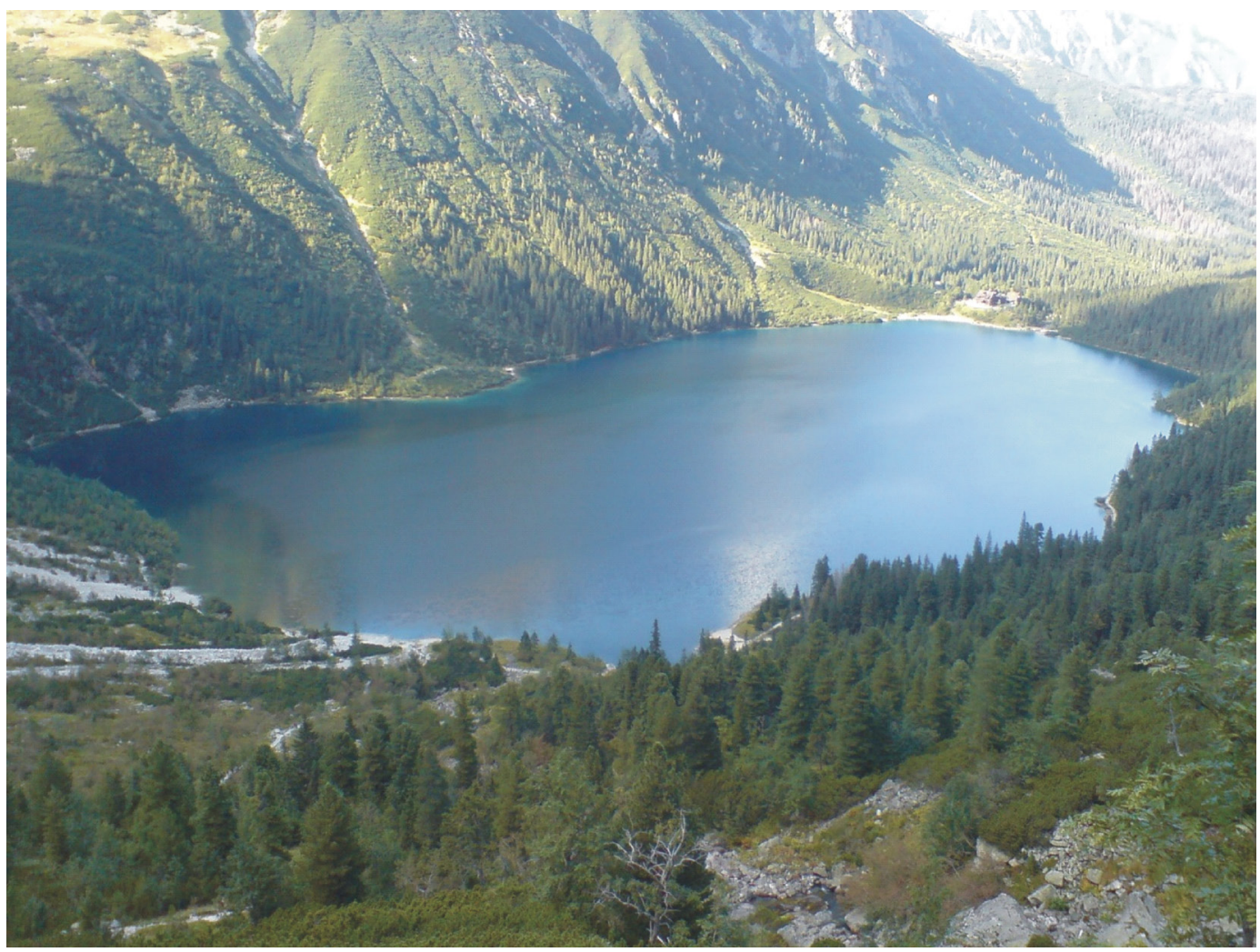

Fig. 2. Morskie Oko - view from route to Czarny Staw pod Rysami

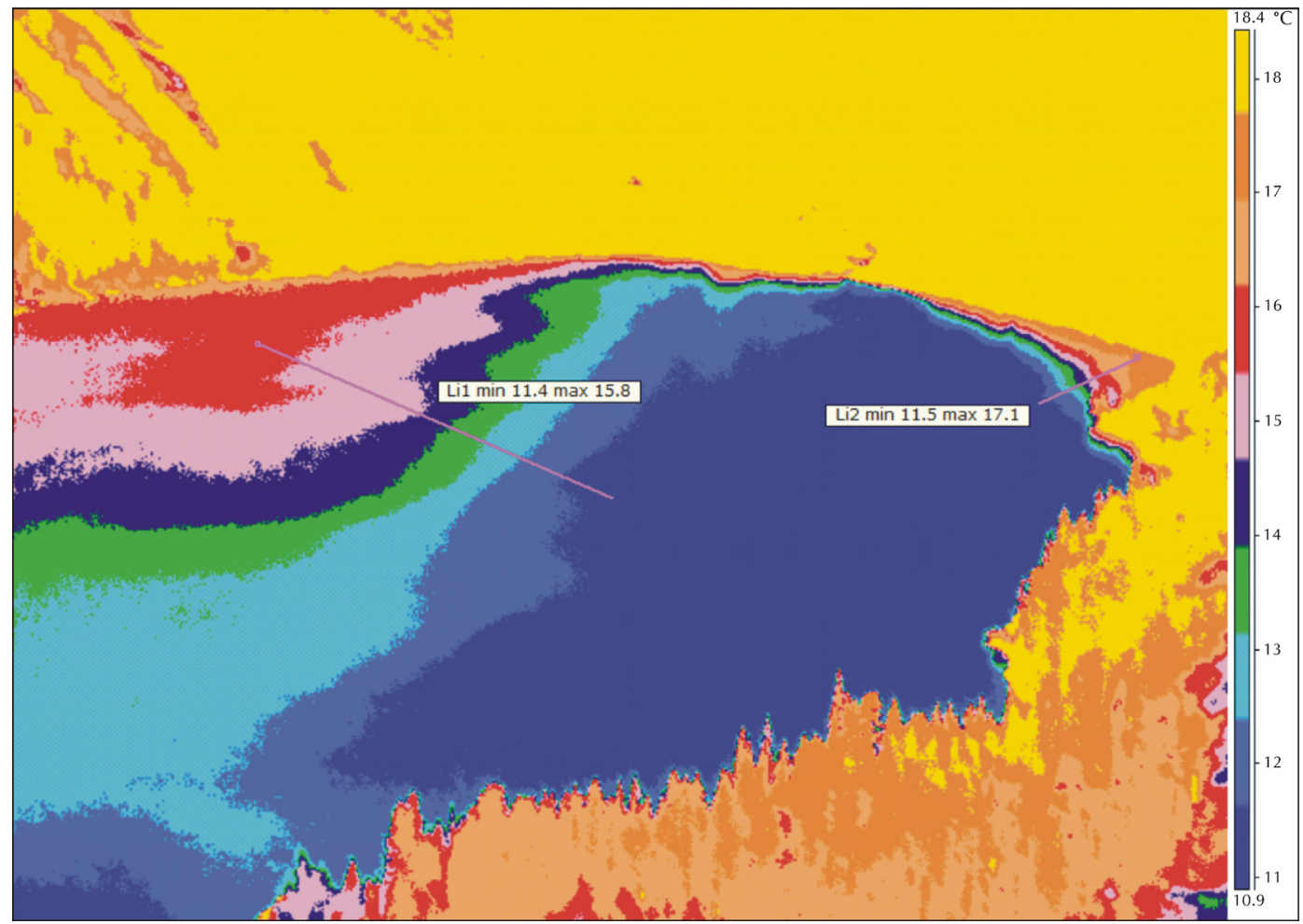

Fig. 3. Thermal photo - north part of Morskie Oko 

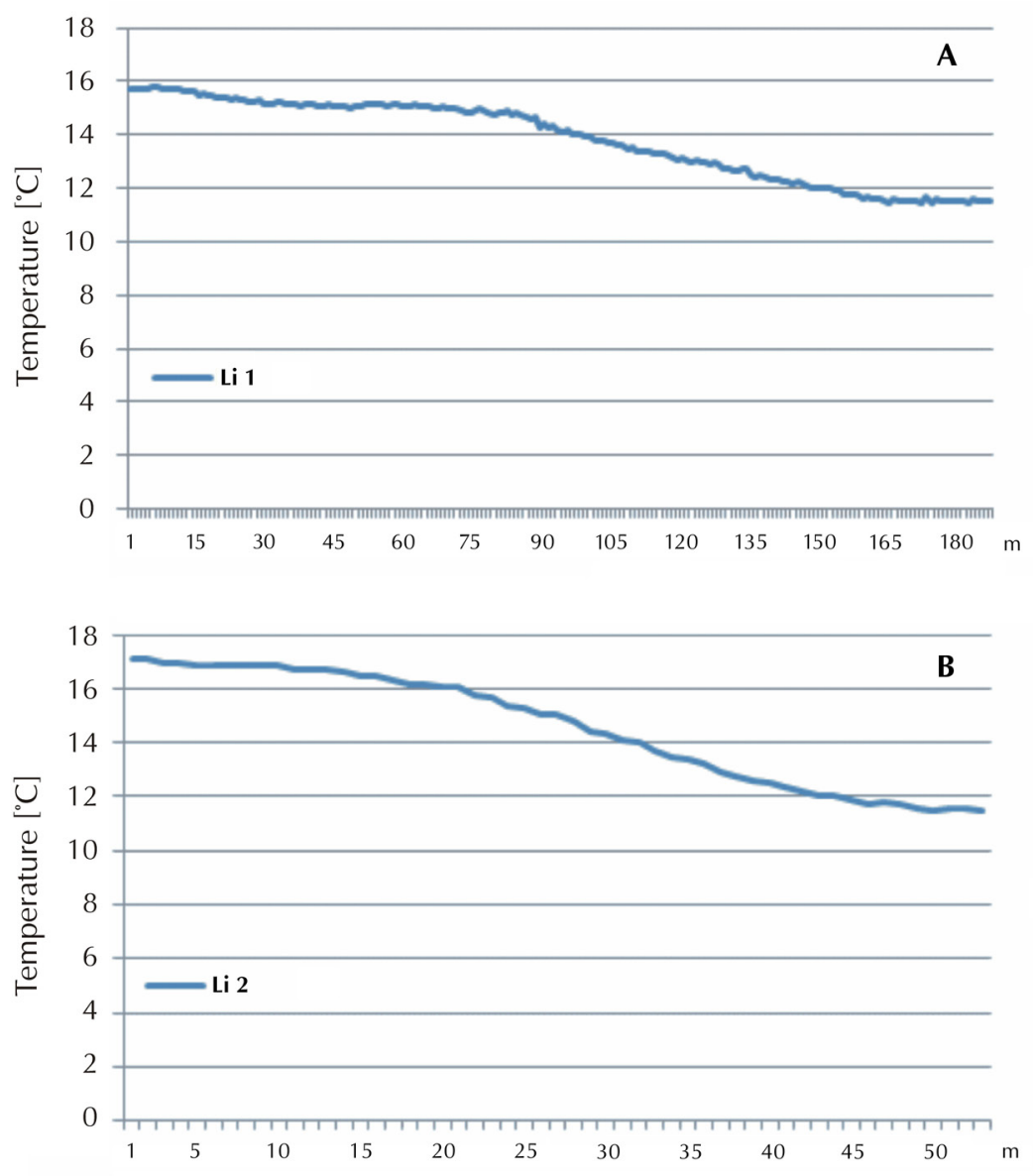

Fig.4. Temperature distribution along Li1 (part A) and Li2 (part B) - Morskie Oko

Figures 5 and 6 show thermal images of the central and southern parts of the lake, respectively. The shot of the lake in the three parts results from the narrow range of the infrared camera angle lens. However, to obtain the image of the whole lake surface the "gluing" of photos with lake fragments can be done. The central part has definitely warmer surface waters than the southern part, which is the most protected part by rock massifs rising at over $1000 \mathrm{~m}$ above the surface of Morskie Oko.

Figure 7 shows Czarny Staw pod Rysami from the location where the thermal photos were taken. In Figure 8 the temperature distribution of the north part of Czarny Staw surface waters is presented. In general waters of Czarny Staw are cooler by several ${ }^{\circ} \mathrm{C}$ than waters of Morskie Oko. It is due to the higher location of Czarny Staw above sea level, it being 200 metres higher. The two profile lines (Li1 and Li2) are marked in the thermal photograph. The differences between the maximum and minimum temperature in a given profile are considerable, being respectively $6.4^{\circ} \mathrm{C}$ and $5.2^{\circ} \mathrm{C}$. In general, the warmest water clings to the shore. However, there is no regularity that the coolest water zone spreads in the central part of the lake and is co-shaped with the configuration of isotherms. Also the cooler waters zone close to the shore is of different width. It can be well observed on the profile lines where on profile Lil the coolest waters (about $6^{\circ} \mathrm{C}$ ) spread approximately 100 metres from the shore but on profile Li2 only about 35 metres from the shore. Fig. 10 presents the south-east fragment of the lake, which is characterized by the largest shallowing. It results from the fact that the $10 \mathrm{~m}$ isobath runs about 70 metres from the shore. In this area there are warmer waters but, what is interesting, not close to the shore itself. The rubble placed just at the surface and several dozen metres from the shore is a very good example showing how water is heated from the rock blocks which are in contact with water. In Figure 10 it is clearly seen that rock blocks covered in water have a temperature several degrees higher than the surface of "open" waters and the zone directly clinging to the 


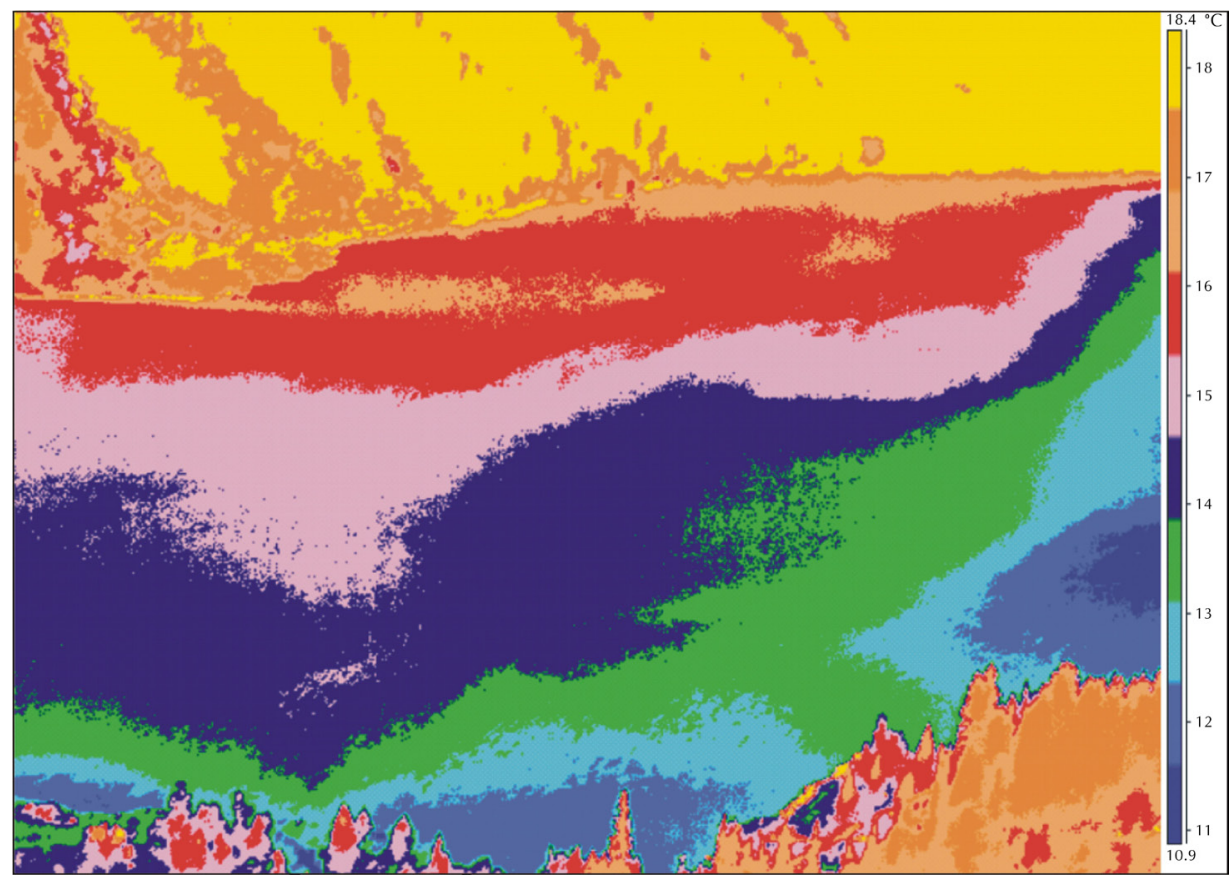

Fig. 5. Morskie Oko - thermal image of its central part

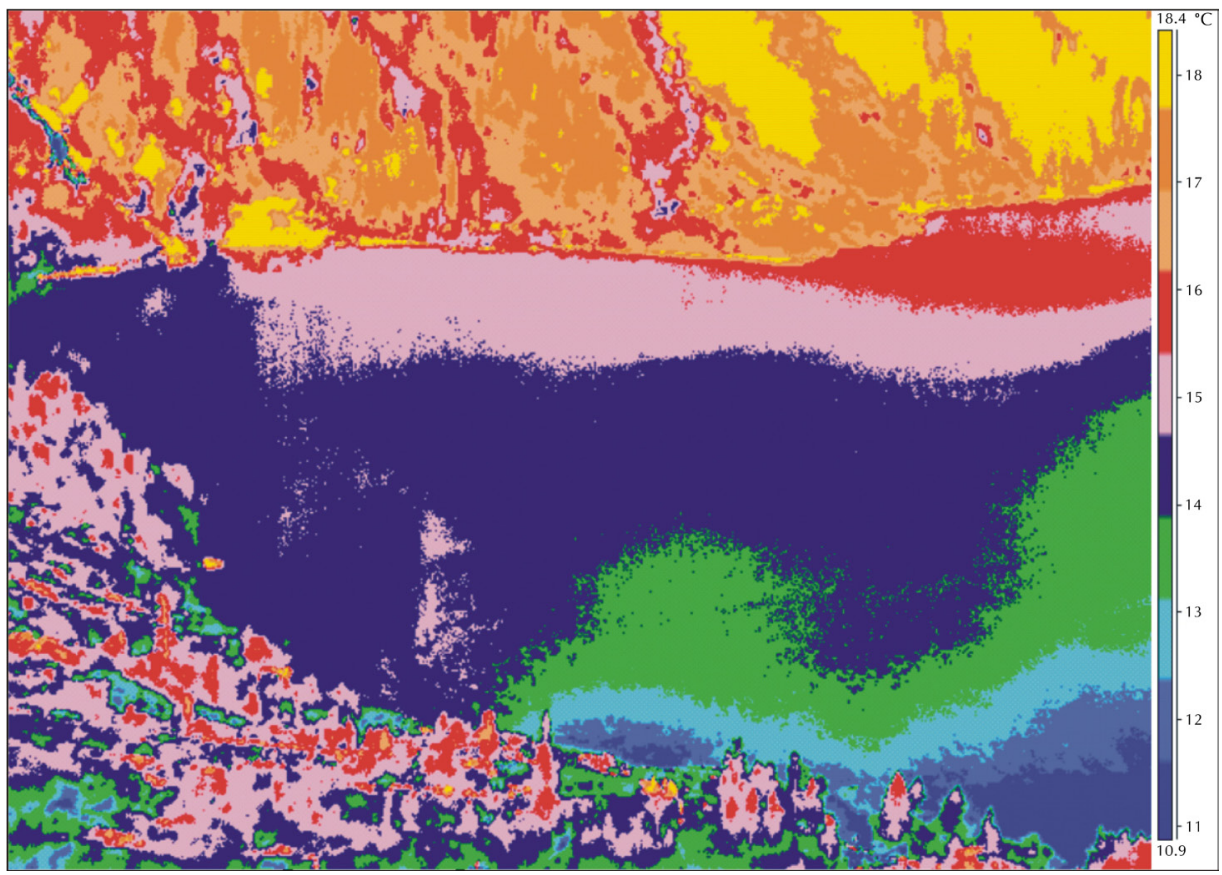

Fig. 6. Thermal photo - southern part of Morskie Oko

blocks has a distinctively higher temperature than waters spread several metres further.

Figure 11 presents the temperature distribution of surface water in the south-west part of the lake. It is the most shadowy zone due to the nearest walls of Kazalnica. In this zone one can observe the diversity of water zone width along the shore with the same temperature range. It is probably the effect of wind impact which moves surface water masses.

Figure 12 shows the north-west shore of Morskie Oko from the place where photographs of the coastal zone were taken. Figures 13 and 14 were taken 


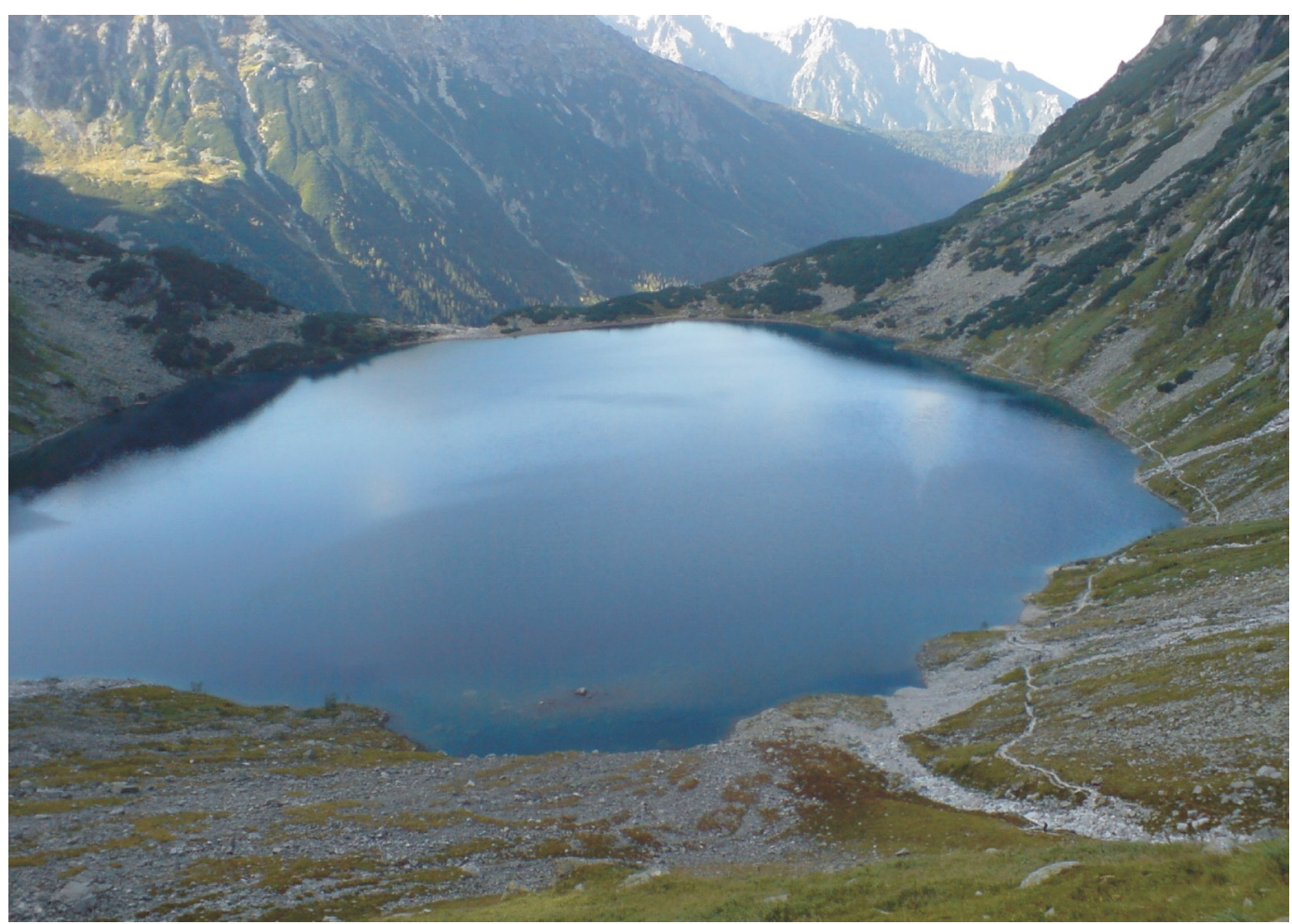

Fig. 7. Czarny Staw pod Rysami - view from route to Rysy

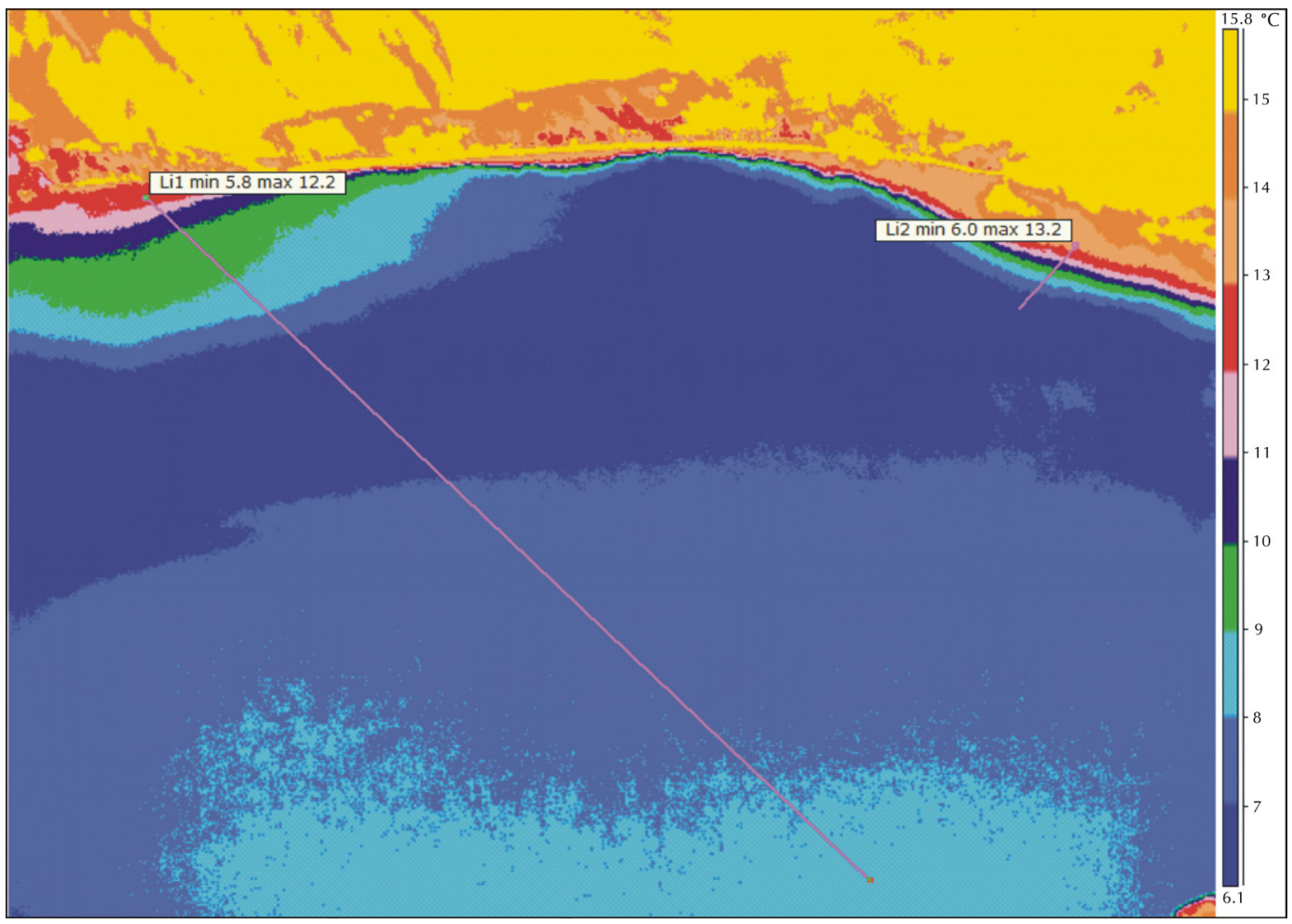

Fig. 8. Thermal photo of north part of Czarny Staw pod Rysami 

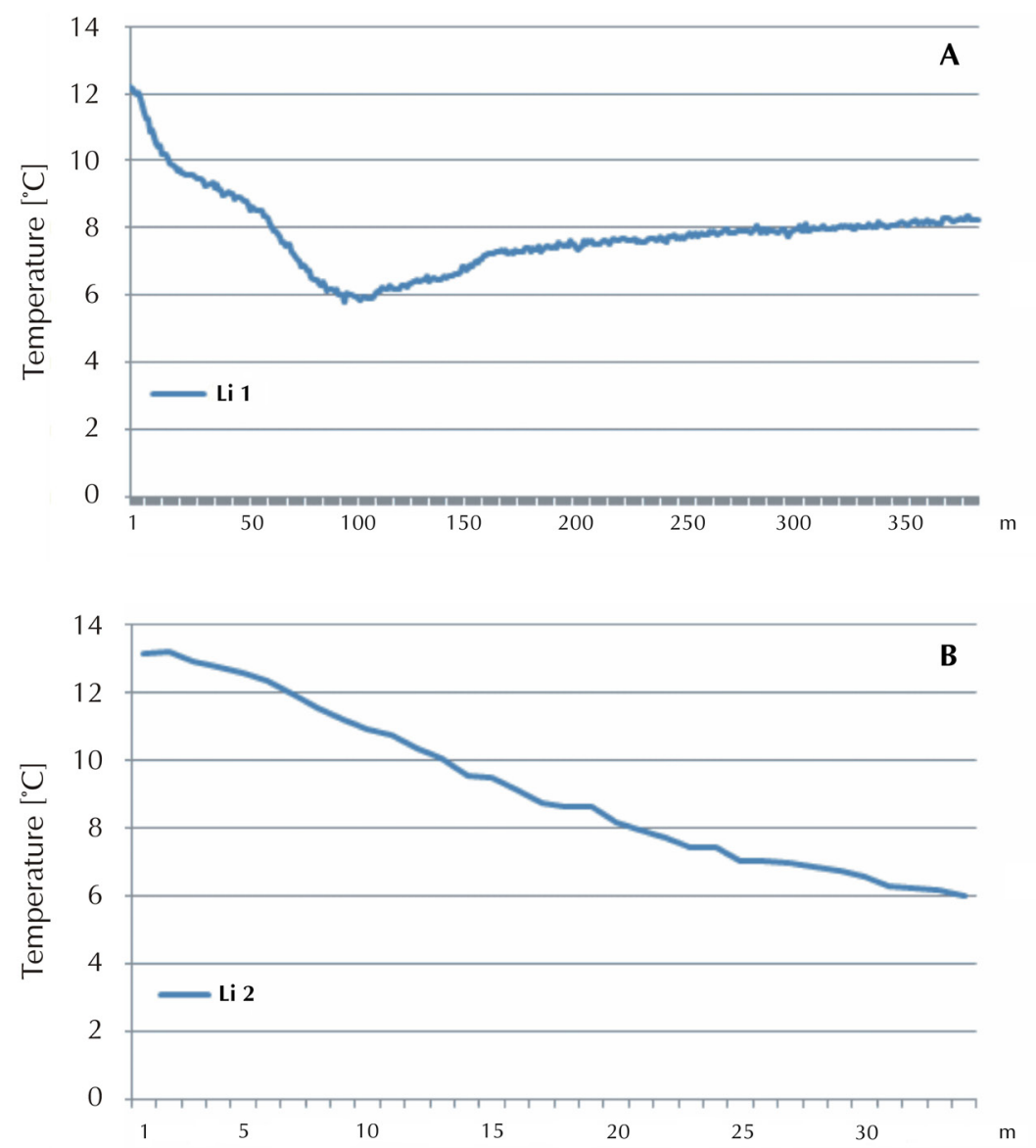

Fig. 9. Temperature distribution along Li1 (part A) and Li2 (part B) - Czarny Staw pod Rysami

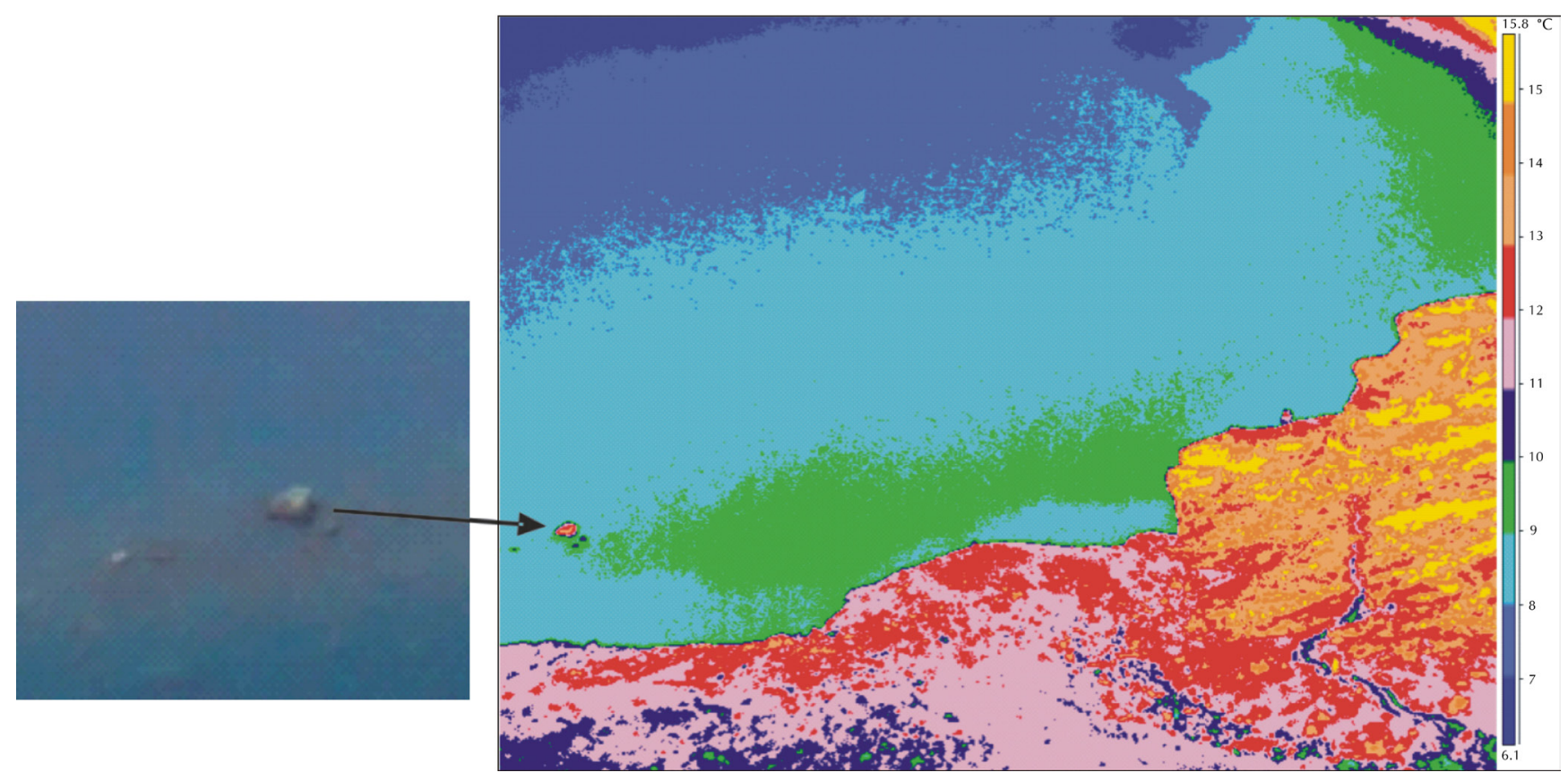

Fig. 10. Thermal photo of south-east fragment of Czarny Staw pod Rysami 


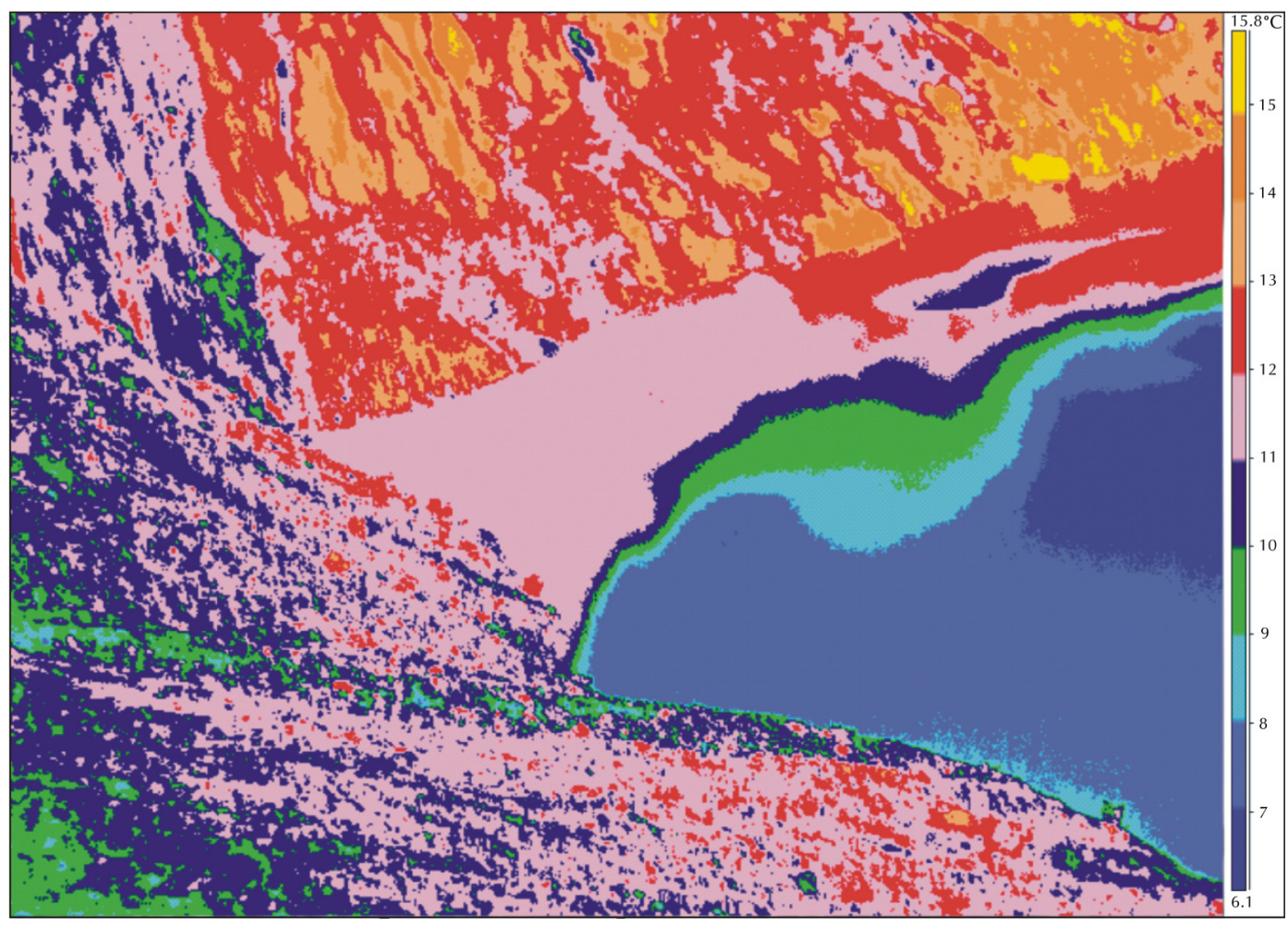

Fig. 11. Thermal photo of south-west part of Czarny Staw pod Rysami

at 9.30 p.m. so in complete darkness. The first photo shows an unusual mosaic of thermal "spots", which are images of the contact of water and rock blocks. Some of them stick out even to 1 metre above the water level, while others are at different depths. A silhouette of a man can be clearly seen - it is the person who is measuring the water temperature with a mercury thermometer. The result of the measurement is necessary to compare it with the results taken from the images of the infrared camera record. Fig.14 shows the same fragment of the lake in different palettes of colours to which adequate temperature scales are assigned.

\section{Conclusions}

The examples of photographs taken by the infrared camera and presented above did not aim to provide a detailed analysis of temperature diversity of waters of the two lakes, but to indicate the great possibilities of applying this type of research. On the one hand they show a continuous temperature record of the whole surface, which is not possible to perform with classic measuring methods (different types of thermometers) In the examples given, the interval every $1^{\circ} \mathrm{C}$ was marked on the temperature axis. In the case of small temperature differences (colours, isotherms), e.g. every $0.2^{\circ} \mathrm{C}$, some separations can be performed.

One of the greatest advantages of using the infrared camera is the possibility of repeating the shots at different time intervals. This way the subsequent stages of water temperature diversity (dynamics and scale) can be followed both during the day and night. In mountain conditions the use of the infrared camera is especially "easy" due to the fact that a plane is not needed. Is there a need and grounds for research of surface water temperature with the use of the infrared camera? Well, the obtained images with unusually large diversity of temperature (which was not known until now) not only encourage further and more detailed research but even require them to begin. Detailed studies of this type will allow limnologists to understand better the processes connected with heating and cooling of waters with the circulation of water masses and the exchange of heat at the interface of land and water. 


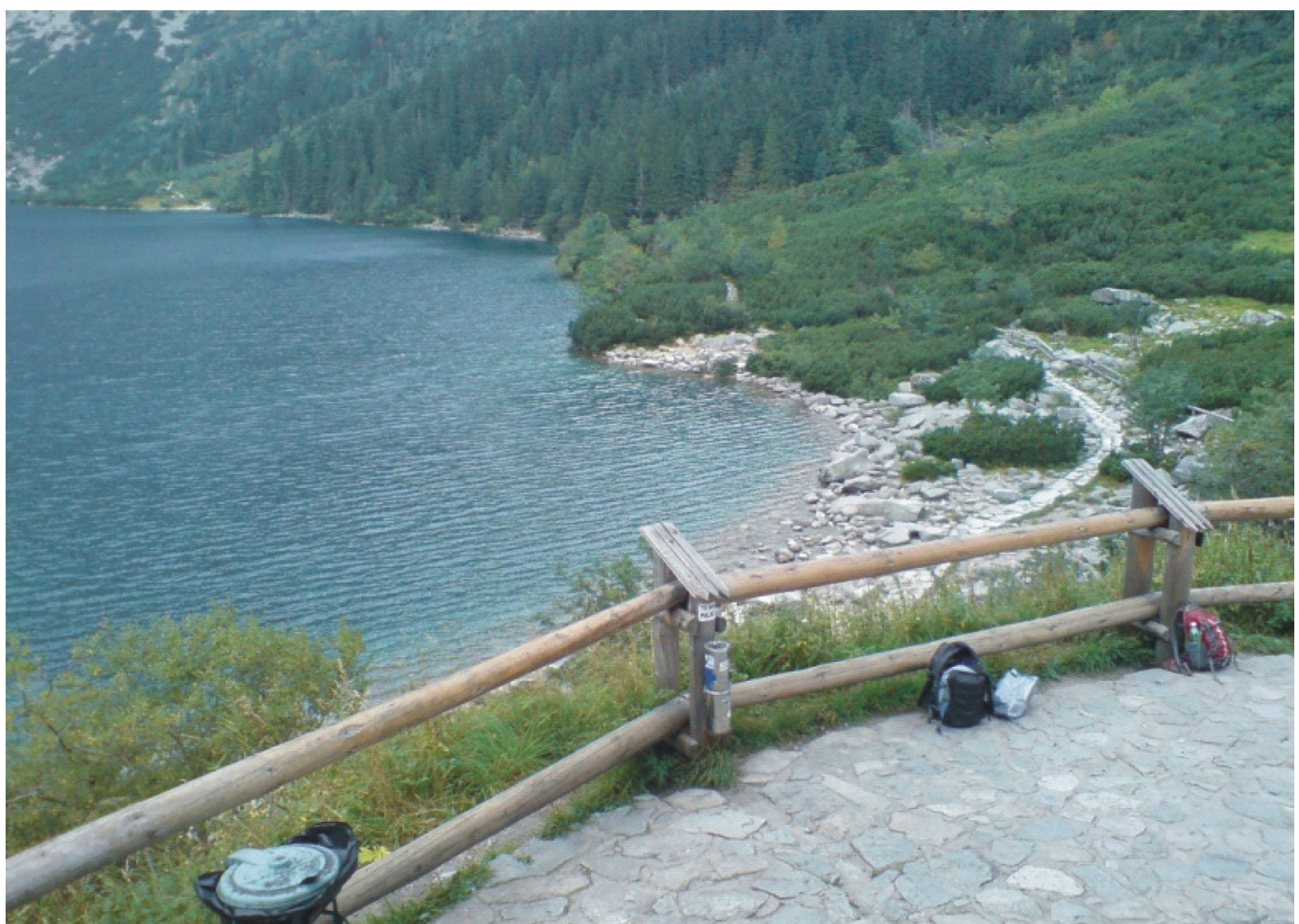

Fig. 12. North-west shore of Morskie Oko from where thermal photos of coastal zones were taken

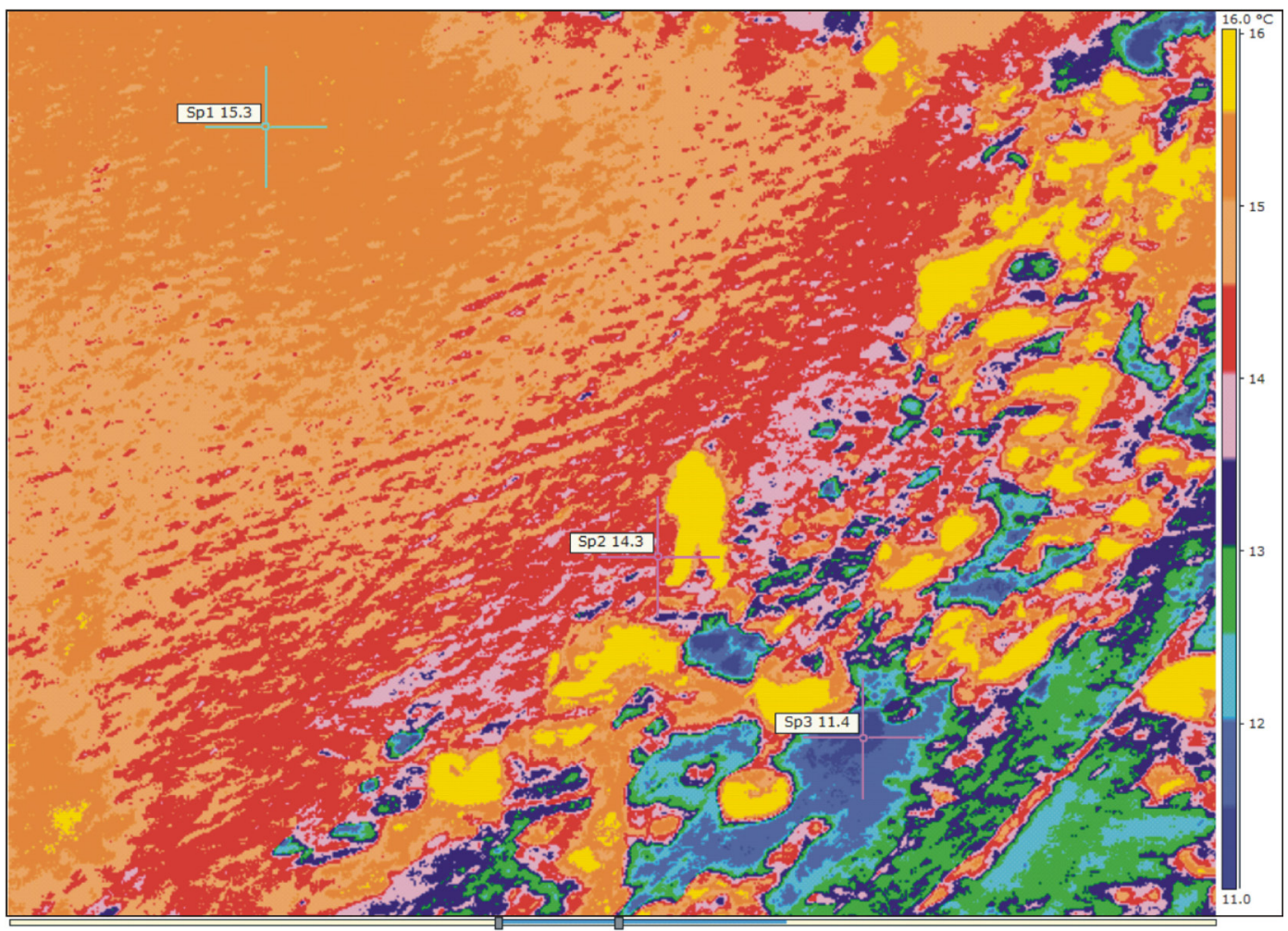

Fig.13. Thermal photo of coastal zone of north-west part of Morskie Oko 

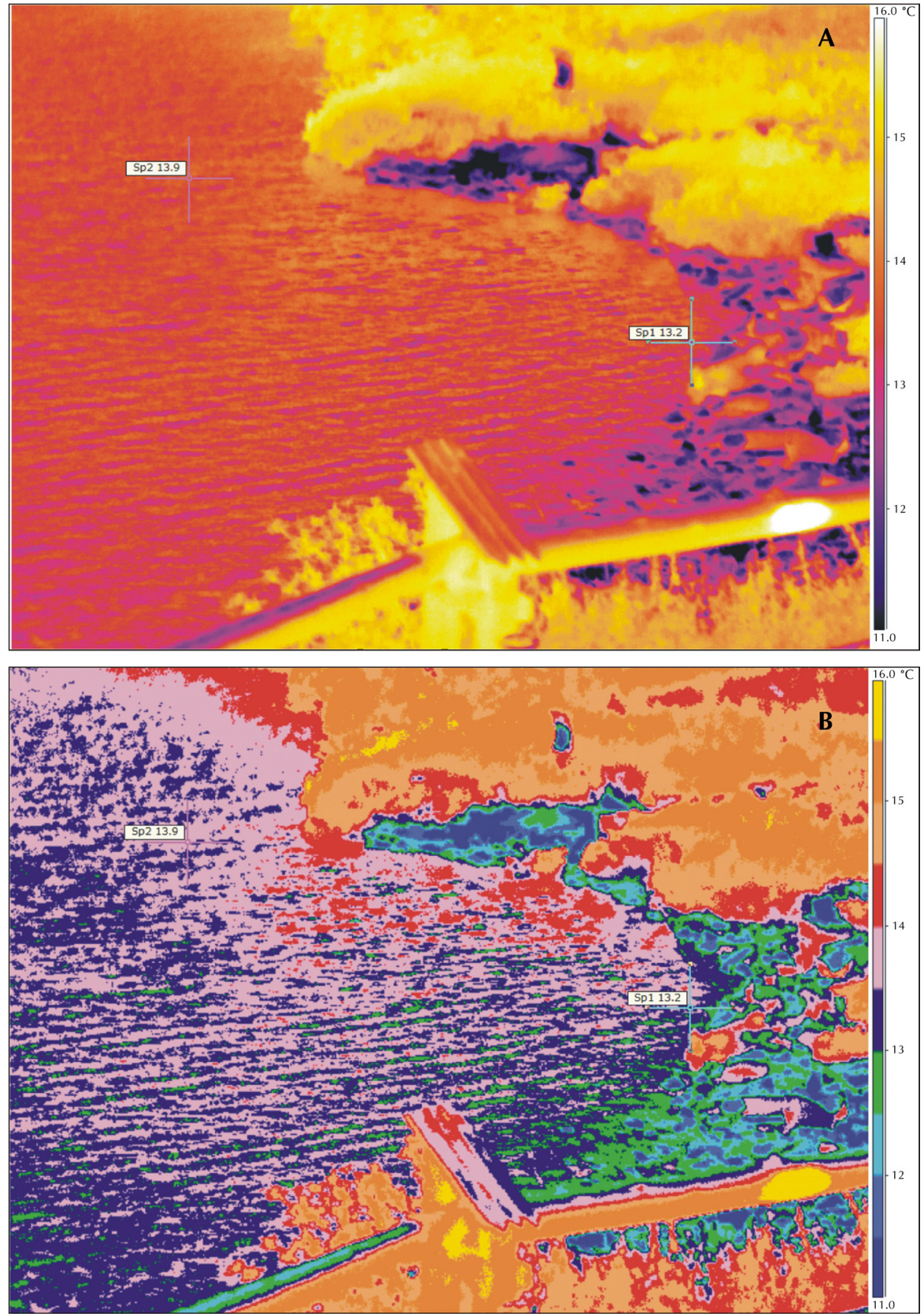

Fig. 14. Thermal photo of north-west shore of Morskie Oko in different palettes of colours (A and B)

\section{References}

Choiński A., 1995, Zarys limnologii fizycznej Polski [An outline of physical limnology of Poland], Wyd. Nauk. UAM, Poznań, p. 298 (in Polish).

Choiński A., 2007, Limnologia fizyczna Polski (Physical limnology of Poland), Wyd. Nauk. UAM, Poznań, p. 547 (in Polish).
Lange W. (ed.), 1993, Metody badań fizyczno-limnologicznych (Methods of physicolimnological studies), Wyd. UG, Gdańsk, p. 175 (in Polish).

Onoszko J., 1979, Zastosowanie metody termowizyjnej w ocenie powierzchniowego rozkładu temperatury wody Jeziora Żarnowieckiego (The application of a thermovisional method to assess the surface distribution of water temperature exemplified by lake Żarnowieckie), Stud. Mat. Oceanol. 26: 327-346 (in Polish). 